\title{
Application of Student Centered Learning (SCL) Method through Discovery Strategies in Vocational Educations
}

\author{
Lietje Lumatauw, Meidy Wollah, Rollyke Tulangow \\ Department of Business Administration, State Polytechnic of Manado, Manado, Indonesia \\ Email: lietje.lumatauw@polimdo.ac.id,meidywollah73@gmail.com,rolyke.tulangow@polimdo.ac.id
}

How to cite this paper: Lumatauw, L. Wollah, M., \& Tulangow, R. (2020). Application of Student Centered Learning (SCL) Method through Discovery Strategies in Vocational Educations. Open Journal of Social Sciences, 8, 82-90.

https://doi.org/10.4236/jss.2020.811008

Received: September 16, 2020

Accepted: November 9, 2020

Published: November 12, 2020

Copyright $\odot 2020$ by author(s) and Scientific Research Publishing Inc. This work is licensed under the Creative Commons Attribution International License (CC BY 4.0).

http://creativecommons.org/licenses/by/4.0/

\begin{abstract}
Vocational education is education that more focused on learning in practice. Vocational education, also known as skill based education, is increasingly popular. In this research, researchers will create a Student Centered Learning (SCL) application method through a discovery strategy, where students can find new ideas, new technology, and the right results to be shared with others. This Student Centered Learning (SCL) method is a student-centered learning approach. In this research, researchers have used class action methods and qualitative approaches, which have been implemented in the Department of Business Administration, Manado State Polytechnic. With the results of Student Centered Learning and the Discovery Strategy variable of 0.825 or in other words, there is a very strong relationship. While the correlation between the Student Centered Learning variable and the Manado State Polytechnic Vocational Education variable is 0.622 which means that's a strong relationship. On the other hand, the correlation between the Discovery Strategy variable and the Vocational Education at Manado State Polytechnic variable is 0.733 which also means that's a strong relationship.
\end{abstract}

\section{Keywords}

SCL Method, Discovery Strategy, Vocational Education

\section{Introduction}

In general, vocational education aims to prepare students to become members of society who have the ability of professional experts to apply, develop and disseminate technology, and strive to use it to improve people's lives and enrich national culture. Specially, vocational education is directed to produce graduates 
who have mastered skills in the field of work and are good at speaking, so that they can be directly absorbed as workers in each industry, government institution or self-employment; this is because the teaching load in the vocational education program has been compiled into skills courses (Polii, 2015; Samponu, Wauran, \& Tampangela, 2017).

Vocational education, in this case the education at the Manado State Polytechnic, is a campus oriented in the field of expertise, where the graduates are students who get applied diplomas. Graduating with a degree of expertise, professional certification, and internship experience makes it often used as a green light for companies or governments in recruiting graduates majoring in vocational studies (Samponu, Wauran, \& Tampangela, 2017). Vocational education, in this case at the Manado State Polytechnic Business Administration Department, is to graduate students who have the skills and expertise, and are good at speaking to express many opinions (Samponu, Wauran, \& Tampangela, 2017).

The reason the researchers chose this title was that researchers wanted to direct students to master the ability in the field of work as workers in industry, government or private institutions and self-employment. With the direction of educators, students will also get new technology themselves. The problem in this study is because the learning system that has been carried out so far is the conventional learning system (faculty teaching), or ordinary learning (Agustina, Saputro et al., 2015).

With this background, this study intends to shift the paradigm to the Student Centered Learning (SCL) method through discovery strategies.

This Student Centered Learning (SCL) method is present as an antithesis to conventional methods. Another reason, so far, still using conventional learning systems or ordinary learning, is that they are less flexible in accommodating learning developments because educators have to intensively adjust theory with the latest technological developments (Haryono, 2017).

In this research, researchers have created a Student Centered Learning (SCL) method through a discovery strategy. The discovery method is a teaching method that regulates teaching in such a way that students acquire previously unknown knowledge not through notification, partially or completely discovered (Arief, 2012; Sari, Jamil et al., 2016). The purpose of this study: 1) To create and test the Students Centered Learning approach method through discovery strategy. 2) Developing student-centered learning methods to foster independent learning. 3) To determine the findings through the Students Centered Learning Method. 4) To find out that the learning outcomes using the SCL approach through discovery strategies are better than conventional learning or ordinary learning. Benefits of research: As an effort to improve learning outcomes and increase understanding and the active role of students in the classroom. With the Students Centered Learning method, it can provide high motivation for students. The results of this study are expected to be used as an effort to improve and increase the quality of learning. 
This Student Centered Learning method is made in a group and this research is in accordance with the Manado State Polytechnic research strategic plan to support learning methods in the field of technology. Our research team consists of 3 people, the head researcher, member 1 and member 2. The task of the chairman is to create the Students Centered Learning method through discovery strategies and together with member 1 has conducted (tested) this method in learning in classes. The task member 2 have evaluated and collected data. After the data was collected, our research team processed the data together, to obtain learning outcomes from the Students Centered Learning Method through a discovery strategy.

\section{Literature Study}

\subsection{Student Centered Learning (SCL) Method}

Small Group Discussion tutorials that make students go to the stage of looking for references, complete "learning objectives" and understand the reference materials they have obtained. Collaborative Learning is approach used for teaching and learning that involves a group of students working together to solve problems, complete assignments or produce products.

Self Directed Learning is a constructivist learning model that is centered on students (student centered). This SDL model is based on the view of John Dewey that every individual has unlimited potential to grow and develop. Contextual Instruction is the concept of learning that helps lecturers relate course content to real situations in everyday life and motivates students to make connections between knowledge and its application in everyday life as members of society, professional or managerial workers, entrepreneurs, and investors. Project Based Learning is innovative student-centered learning and places educators as motivators and facilitators, where students are given the opportunity to work autonomously and construct their learning. Problem Based Learning and Inquiry is a problem-based learning that will lead students to real problem situations. Real problems are needed in the learning process to improve students' learning abilities (Nuz'miah, 2016).

Student Centered Learning (SCL) is a learning model that is currently popular in the world of education, which itself means a student-centered learning process. According to UU (law) number 20 of 2003 concerning the National Education System and Law of the Republic of Indonesia number 13 of 2012 concerning higher education, it is stated that learning is the interaction between educators, students and learning resources in a particular learning environment (Haryono, 2017).

\subsection{Strategy Discovery Steps}

The concepts or principles that students must discover through these activities need to be written clearly. Tools or materials need to be provided in accordance with the needs of students in carrying out activities. The discussion as a direction before students carries out activities. The critical thinking process needs to be explained to show the operational mentality of students, which is expected in student activities. It is necessary to develop open questions, which lead to the ac- 
tivities carried out by students. There are educator notes that include explanations of difficult issues and factors that could affect the results, especially if the investigation failed or did not work properly.

According to Bruner, learning is best when students discover information and concepts on their own. In discovery learning, students use inductive reasoning to derive principles and examples. Bruner believes that students can have knowledge if they find themselves and are responsible for their own learning activities, which motivate them to learn (Setiarini, 2016).

\subsection{Vocational Education}

Student Centered Learning (SCL) in Vocational Education takes the Student Centered Learning (SCL) method and through discovery strategies, so that students can find results, new ideas and technological result in one method that are also proficient in speaking. With this method, it can fulfill the Institutional Strategic Plan in the learning process that produces one method (Prassida \& Muklason, 2012).

\section{Research Methods}

\subsection{Method}

This research is a classroom action research. While the approach used in this research is qualitative research. The research location is located at Manado State Polytechnic, Business Administration Department. Data collection techniques, namely observation and using documents research questionnaire. Data analysis technique is the process of arranging data sequence and organizing it into a pattern.

\subsection{SCL Products/Applications through the Discovery Strategy}

\section{1) Start Menu}

Contains the title of the application (red circle) and a button to start (START button).

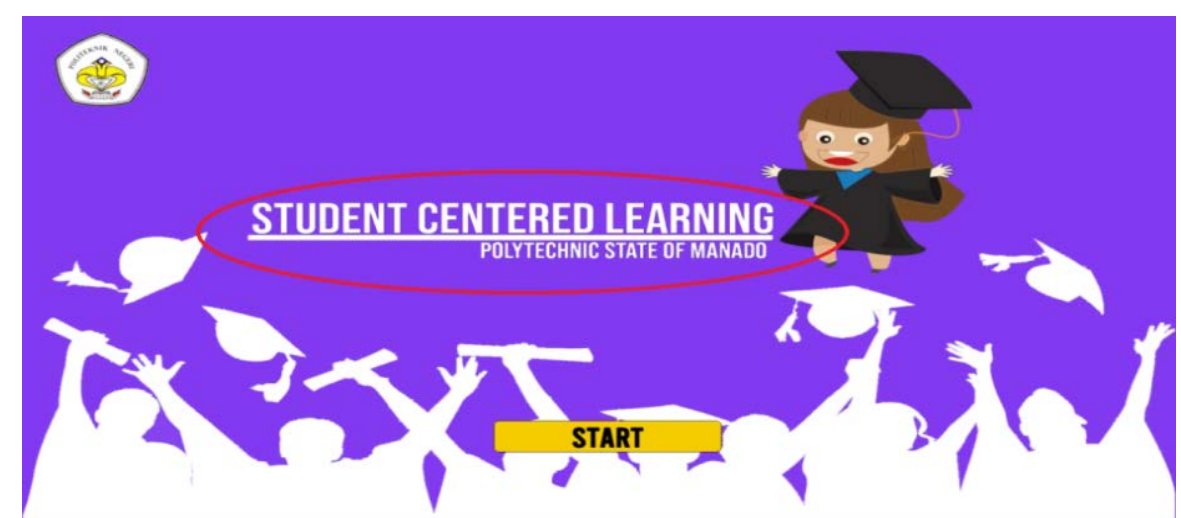

\section{2) Main Menu}

Contains the main menu of the application. Numbers 1 to 4 are a button to access one of the 4 chapters. Number 5 is the access button to the about menu, and number 6 is the button to exit. 


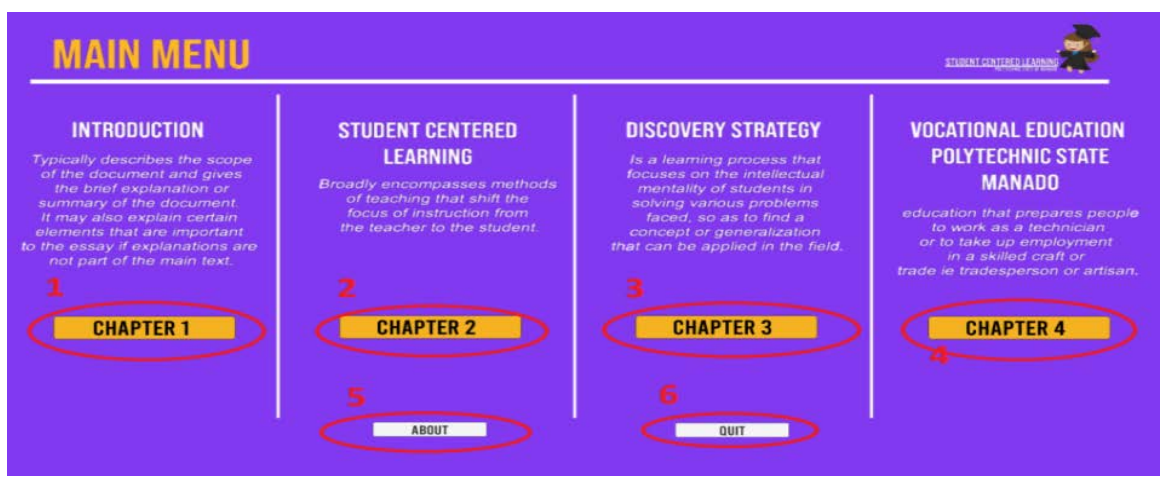

\section{3) Chapter 1: Introduction}

Contains an introduction to the material and an introduction to the Student Centered Learning application (There is a BACK button to return to the main manu).

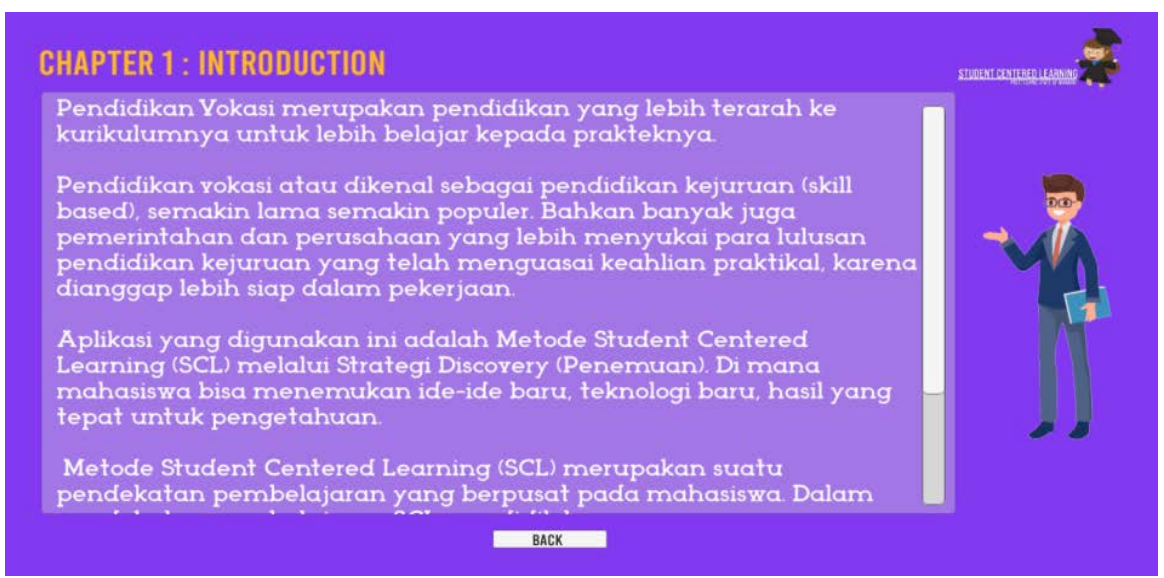

\section{4) Chapter 2: Student Centered Learning}

Contains Student Centered Learning material (There is a BACK button to return to the main manu).

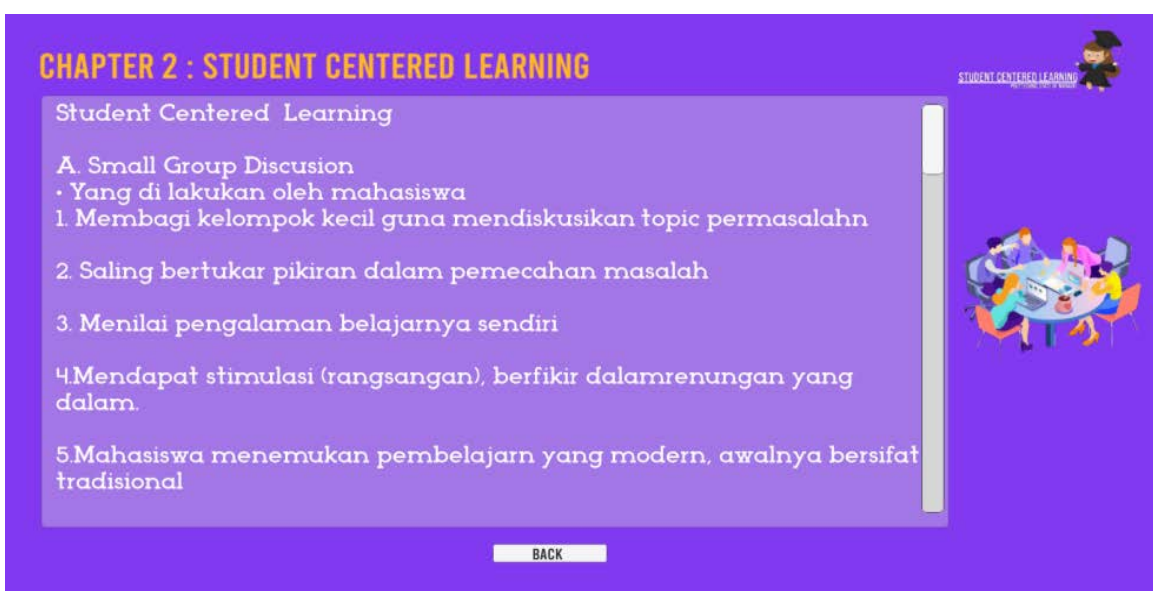

\section{5) Chapter 3: Discovery Strategy}

Contains theory from Discovery Strategy (There is a BACK button to return to the main manu). 


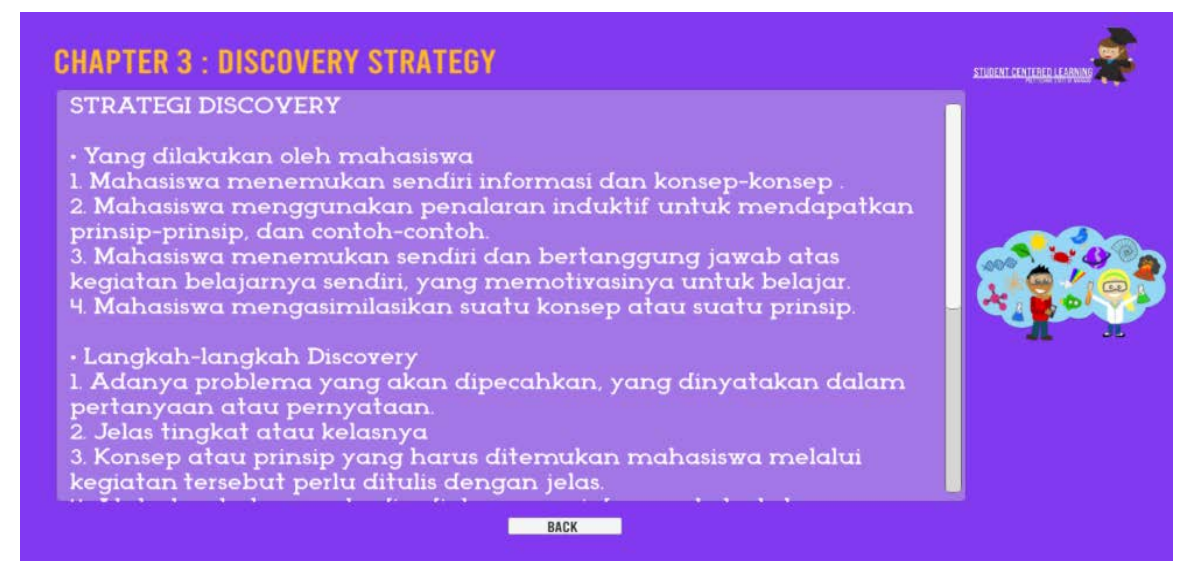

\section{6) Chapter 4: Vocational Education Polytechnic State of Manado}

Contains the vision and mission of Manado State Polytechnic (There is a BACK button to return to the main menu).

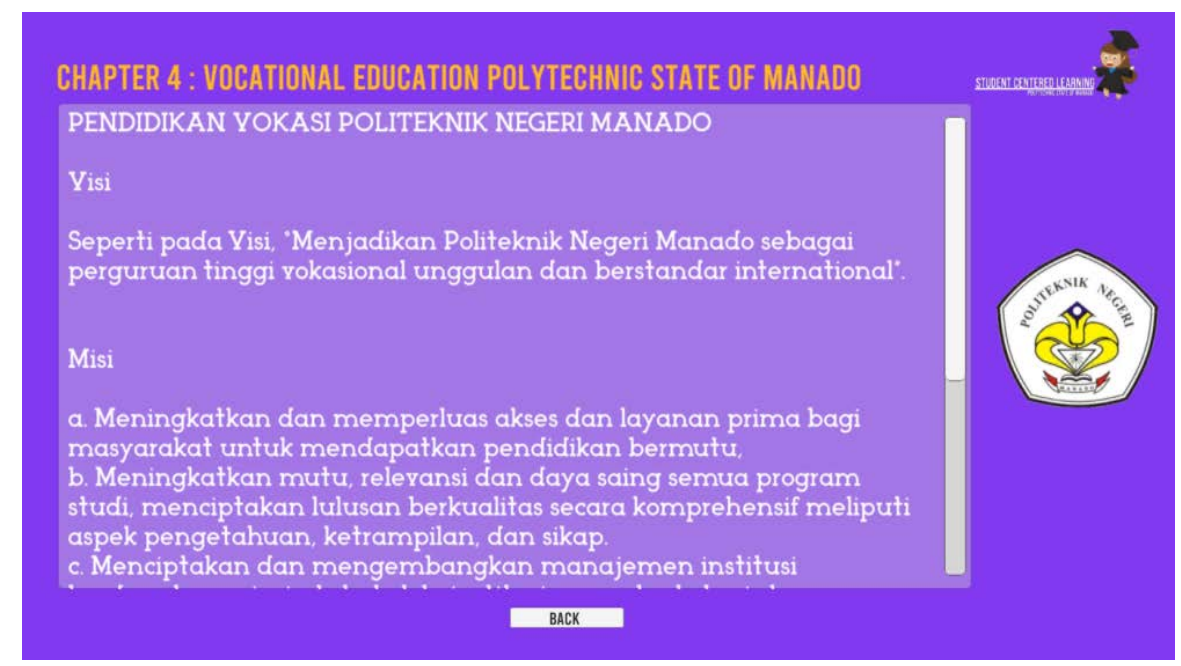

\section{7) About}

Contains the name of the application maker, the engine used in making the application, and the copyright of this application (There is a BACK button to return to the main manu).

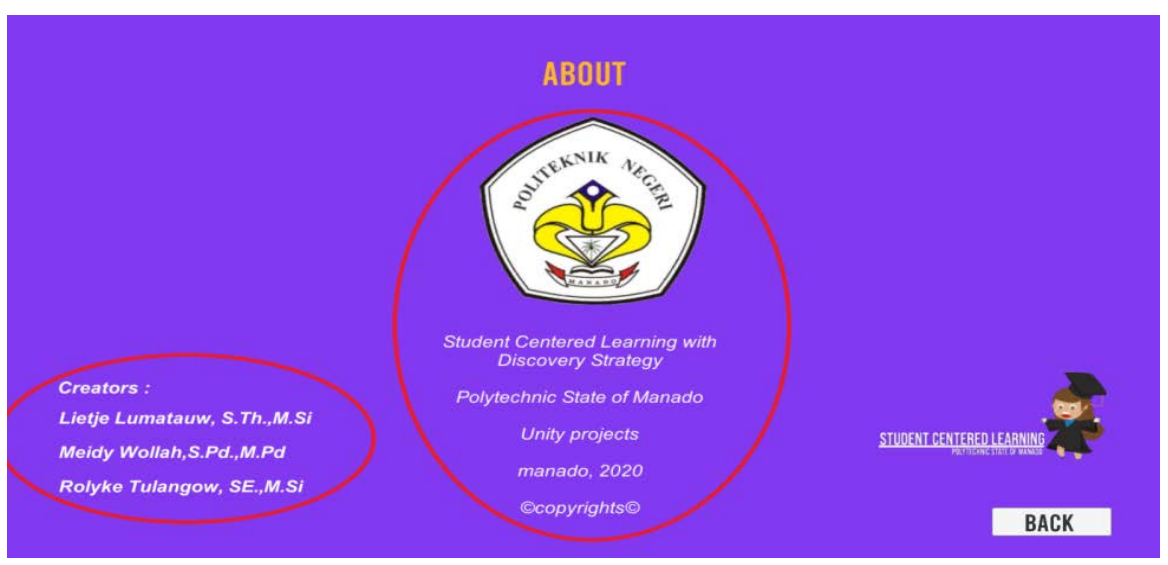




\subsection{Flowchart Application}

Flowchart is a schematic or chart that describes the sequence of activities from one program from the beginning to the end. The purpose of a flowchart is to know the workflow of a program when the program is running.

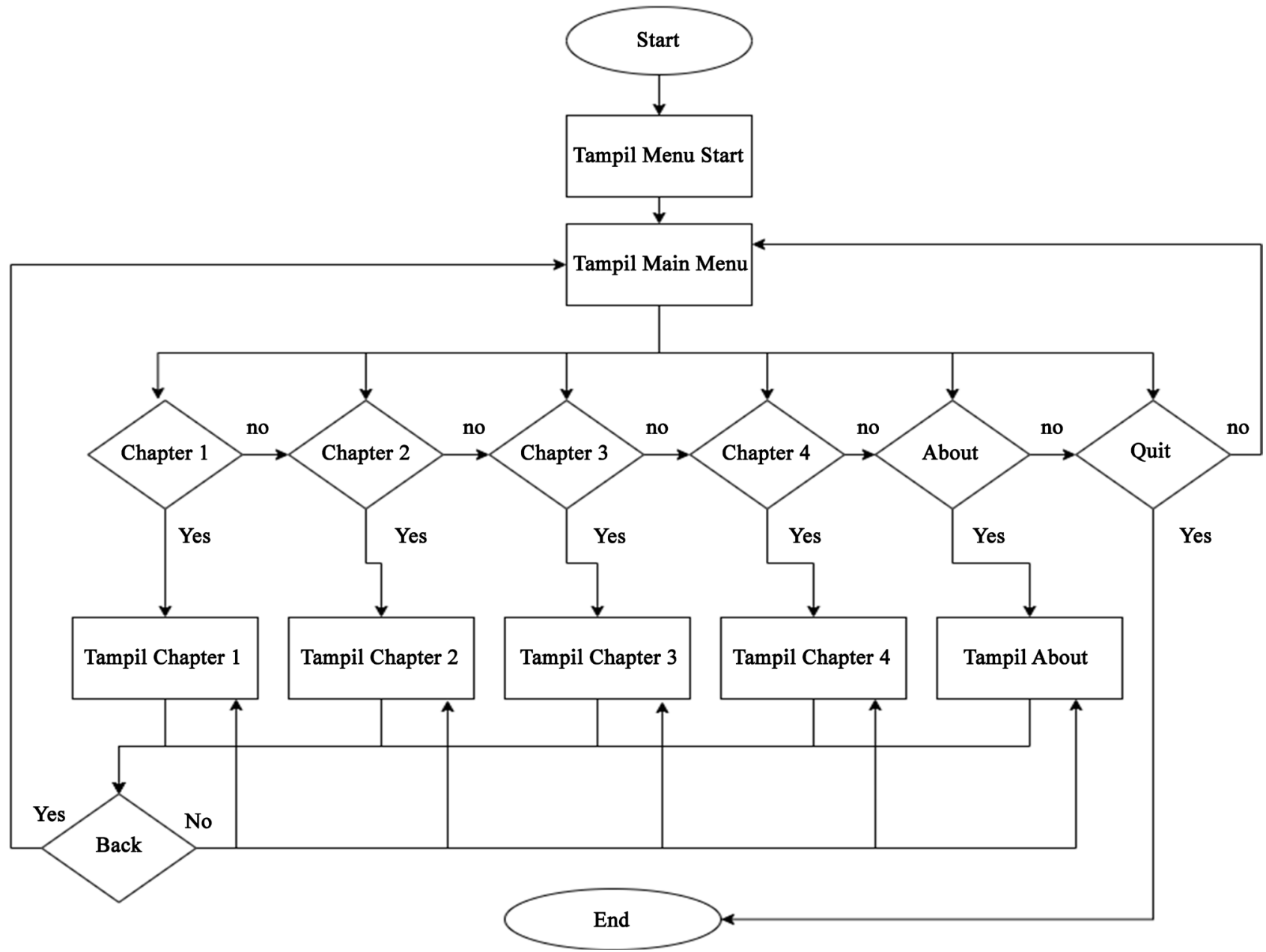

\section{Results and Discussion}

\section{Correlation Analysis Results}

In this table, the partial correlation analysis results are presented to find out the relationship between each variable in this study: Student Centered Learning as the first variable (V1), Discovery Strategy as the second variable (V2), and Manado State Polytechnic Vocational Education as the third variable (V3).

Table 1 explains that the correlation or relationship between the Student Centered Learning variable and the Discovery Strategy variable is 0.825 or in other words, the Student Centered Learning variable and the Discovery Strategy variable have a very strong relationship. While the correlation between the Student Centered Learning variable and the Manado State Polytechnic Vocational Education variable is 0.622 or in other words, the Student Centered Learning variable and the Manado State Polytechnic Vocational Education variable have a 
Table 1. Correlations analysis result.

\begin{tabular}{ccccc}
\hline \multicolumn{3}{c}{ Correlations } & & \\
\hline & & V1 & V2 & V3 \\
\hline Pearson Correlation & V1 & 1.000 & 0.825 & 0.622 \\
& V2 & 0.825 & 1.000 & 0.733 \\
& V3 & 0.622 & 0.733 & 1.000 \\
Sig. (2-tailed) & V1 & & 0.014 & 0.025 \\
& V2 & 0.014 & & 0.019 \\
N & V3 & 0.025 & 0.019 & \\
& V1 & 80 & 80 & 80 \\
& V2 & 80 & 80 & 80 \\
& V3 & 80 & 80 & 80 \\
\hline
\end{tabular}

strong relationship. Likewise, the correlation between the Discovery Strategy variable and the Manado State Polytechnic Vocational Education variable is 0.733 or in other words, the Discovery Strategy variable and the Manado State Polytechnic Vocational Education variable have a strong relationship. Table 1 also shows that the calculation of the correlation has been significant, it can be seen in the significance value of 0.05 where all the Sig values between variables are below the value of 0.05 so it can be said that all the results of the correlation calculations are significant.

\section{Conclusion}

Student Centered Learning (SCL), is learning that is more emphasized on student activity. The purpose of the Student Centered Learning (SCL) model through discovery itself is to improve the quality of learning carried out by educators, optimally develop student potential in teaching and learning activities, and is a discovery in a mental process which expects students to assimilate a concept or a principle. Therefore Student Centered Learning (SCL) through discovery is an appropriate learning method. This is very useful in vocational education, in this case vocational education at Manado State Polytechnic, Business Administration Department. With the results of Student Centered Learning and the Discovery Strategy variable of 0.825 or in other words, there is a very strong relationship. While the correlation between the Student Centered Learning variable and the Manado State Polytechnic Vocational Education variable is 0.622 or in other words, there is a strong relationship. Likewise, the correlation between the Discovery Strategy variable and the Manado State Polytechnic Vocational Education variable is 0.733 or in other words there is a strong relationship. Student Centered Learning has the potential to encourage students to learn more actively, according to the style, pace and rhythm of each individual learning. And also the rhythm of learning needs to be guided so that it continues to be dynamic and has a high level of competence, with this research, in order to be useful for lecturers, 
students and society.

\section{Conflicts of Interest}

The authors declare no conflicts of interest regarding the publication of this paper.

\section{References}

Agustina, E., Saputro, A. N. C., Mulyani, S., Berbantuan, P. M. P. J., Negeri, X. S., Ajaran, G. T., Ardian, A., \& Munadi, S. (2015). Pengaruh Strategi Pembelajaran Student-Centered Learning dan Kemampuan Spasialterhadap Kreativitas Mahasiswa. Jurnal Pendidikan Teknologidan Kejuruan.

https://journal.uny.ac.id/index.php/jptk/article/view/7843/6715

Arief, R. (2012). Usaha Peningkatan Kompetensi Softskillmelalui Student Centered-Learning Bagi Mahasiswa yang Mengikuti Mata Kuliah Analisa Perancangan Sistem. Jurnal Pendidikan Teknologidan Kejuruan.

http://file://C:/Users/Asus/Downloads/3336-8599-1-PB\%20(6).pdf

Haryono, A. (2017). Metode Student Centered Learning (SCL) dalam Pembelajaran Bahasa Asingdengan Media Berbasis E-Learning: Upaya Meningkatkan Peran Aktifdan Kreativitas Mahasiswa. repository.unej.ac.id. https://repository.unej.ac.id/handle/123456789/83757

Nuz'miah, A. (2016). Cooperative Learning Suatu Kajian Dalam Lingkup Student Centered Learning (SCL): Pengertian, Teoridan Karakteristiknya. Jurnal Pendidikan Dasardan Menengah. http://www.jupedasmen.com/index.php/JUPEDASMEN/article/view/89/83

Polii, B. D. (2015). Evaluasi Program Implementasi Manajemen Mutu Pada Politeknik Negeri Manado. PEDAGOGIA Jurnal Ilmiah Pendidikan.

http://repository.polimdo.ac.id/836

Prassida, G. F., \& Muklason, A. (2012). Virtual Class Sebagai Strategi Pembelajaran Untuk Peningkatan Kualitas Student-Centered Learning Di Perguruan Tinggi. Prassida, 1. http://www.journal.unipdu.ac.id/index.php/teknologi/article/view/55 https://doi.org/10.26594/teknologi.v1i2.55

Samponu, Y. B., Wauran, A. S., \& Tampangela, H. R. K. (2017). Analisis Sistem Informasi Strategis Pada Politeknik Negeri Manado. POSITIF: Jurnal Sistem dan Teknologi Informasi, 3, 1-5. https://ejurnal.poliban.ac.id/index.php/Positif/article/view/407 https://doi.org/10.31961/positif.v3i1.407

Sari, Y. I., Jamil, A. M. M., \& Jayanti, M. A. (2016). Effect of PBL "Learning Model on Critical Thinking Skills Students Learning Course Design of Geography”. In 1st International Conference on Geography and Education. Atlantis Press. https://www.atlantis-press.com/proceedings/icge-16/25875221

Setiarini, A. (2016). Meningkatkan Motivasi dan Hasil Belajar Peserta Didik dengan Mengoptimalkan Penerapan Pendekatan Saintifik Strategi Discovery Learning dan Metode Diskusi di SDN Model Mataram. Jurnal Kependidikan. Jurnal Hasil Penelitiandan Kajian Kepustakaan di Bidang Pendidikan, Pengajarandan Pembelajaran, 2. http://ojs.ikipmataram.ac.id/index.php/jurnalkependidikan/article/view/390 